\title{
CONTENTS VOLUME 7 (1989)
}

Editorial

Management and qualitative and quantitative evaluation of library school teachers in China WU GUANG-WEI

Inhouse training for information technology

R.F. GUY

Non-professional information and training

K. BEALES

Information technology used for education for information in the Maiduguri Library School, Nigeria

K.M.C. NWEKE

Report

FID Education and Training Committee Report for 1987-1988

Book Reviews

News

Translations of Abstracts

Calendar of Events

Editorial

Online: in an educational cul-de-sac?

N. ROBERTS

Computer-aided instruction in a law library

R. BUNNAGE

Use of the INSTRUCT text retrieval program at the Department of Information Studies, University of Sheffield

P. WILLETT and F.E. WOOD

Elf update (Short Communication)

G. MARTIN

Issues in library research (Short Communication)

Conference Report

Reports from the Schools 
Translations of Abstracts $\quad 195$

Calendar of Events $\quad 197$

$\begin{array}{ll}\text { Editorial } & 201\end{array}$

Education and training for librarianship and information work: Annual Bibliography, 1988 A.J. CLARK

Strategic planning for the 1990s: a challenge for change

M.L. PAO and R.M. WARNER

The documentalist in Spain

M. CARIDAD and P. PORTELA

Reports from the Schools

Book Reviews

News

Translations of Abstracts

Calendar of Events

Editorial

Information intermediaries for industry in Portugal: a training programme and its impact M.J. BARRULAS, A.M.R. CORREIA and T.D. WILSON

Showing them how to mean business: teaching business information to health sciences librarians S.J. BELL

Business information curricula: an employer's list of essential skills and knowledge H. BUTCHER

Providing information for and to business students

W. BRACE and M.E.D. KOENIG

Understanding managerial principles and practices: management training for business information professionals

S. JAMES

A review of the literature of business information education

M.A. LOWE

Translations of Abstracts

Calendar of Events

Author Index Volume 7 